\title{
ANALISIS PENGARUH PEMODELAN SAMBUNGAN TITIK BUHUL PADA STRUKTUR KUBAH GEODESIK
}

\author{
Rivven Meilvin $^{1}$ dan Leo S. Tedianto ${ }^{2}$ \\ ${ }^{1}$ Program Studi Sarjana Teknik Sipil, Universitas Tarumanagara, JL. Letjen S. Parman No.1 Jakarta \\ rivven.325160145@stu.untar.ac.id \\ ${ }^{2}$ Program Studi Sarjana Teknik Sipil, Universitas Tarumanagara, JL. Letjen S. Parman No.1 Jakarta \\ leotedi@ft.untar.ac.id
}

Masuk : 20-01-2021, revisi: 28-01-2021, diterima untuk diterbitkan : 31-05-2021

\begin{abstract}
The geodesic dome consists of steel rod elements joined together to form a single structure. Generally, these geodesic domes are analyzed by assuming the joints of the gusset points are joints and only receive axial forces on the rods. However, in reality, it is not easy to apply gusset joints as pure joints in construction. This research will analyze the geodesic dome by modeling the joints of the gusset points as joints where there is only axial force arising on the rods and modeling the rigid gusset points where there will also be moments and shear on the rods. The analysis will only be carried out by comparing the value of the displacement at each gusset joint modeling and checking the crosssectional dimensions of the internal forces that arise with the help of the MIDAS GEN program in modeling the geodesic dome structure which has a diameter of $20000 \mathrm{~mm}$ and a height of $10000 \mathrm{~mm}$ with the type of steel profile. used is a pipe profile using two types of geodesic dome, namely type $2 \mathrm{~V}$ and $3 \mathrm{~V}$. For loads that are calculated, namely dead load, live load, and wind load. The results showed a relatively small difference in translational displacement and the axial force was relatively the same in the internal force analysis, so it is better if the analysis by modeling the gusset connection as rigid.
\end{abstract}

Keywords: Geodesic dome; knot point connection; rigid; joint; displacement

\begin{abstract}
ABSTRAK
Kubah geodesik terdiri dari elemen batang baja yang disambung menjadi satu kesatuan struktur. Umumnya kubah geodesik ini dianalisis dengan menganggap sambungan titik buhulnya berupa sendi dan hanya menerima gaya aksial saja pada batang - batangnya. Namun pada kenyataannya untuk mengaplikasikan sambungan titik buhul sebagai sendi murni pada konstruksi tidaklah mudah. Penelitian ini akan menganalisis kubah geodesik dengan memodelkan sambungan titik buhulnya sebagai sendi dimana hanya ada gaya aksial saja yang timbul pada batang - batangnya dan memodelkan titik buhulnya rigid dimana akan terjadi juga momen dan geser pada batang tersebut. Analisis hanya akan dilakukan dengan membandingkan nilai dari perpindahan pada setiap pemodelan sambungan titik buhul dan pengecekan dimensi penampang terhadap gaya - gaya dalam yang timbul dengan bantuan program MIDAS GEN dalam memodelkan struktur kubah geodesik yang mempunyai diameter $20000 \mathrm{~mm}$ dan tinggi $10000 \mathrm{~mm}$ dengan jenis profil baja yang digunakan adalah profil pipa dengan menggunakan dua tipe kubah geodesik yaitu tipe $2 \mathrm{~V}$ dan $3 \mathrm{~V}$. Untuk beban yang diperhitungkan yaitu beban mati, beban hidup, dan beban angin. Hasil penelitian menunjukkan nilai perbedaan yang relatif kecil pada perpindahan translasi dan diperoleh gaya aksial yang relatif sama pada analisis gaya dalam yang timbul, sehingga sebaiknya analisis dengan pemodelan sambungan titik buhul sebagai rigid.
\end{abstract}

Kata Kunci: Kubah geodesik; sambungan titik buhul; rigid; sendi; perpindahan

\section{PENDAHULUAN}

Pembangunan di Indonesia terus berkembang seiring waktu berjalan, berbagai macam dan bentuk pembangunan telah dilakukan sampai sekarang. Salah satu bentuk yang telah dibuat di Indonesia adalah bangunan yang berbentuk struktur cangkang. Struktur cangkang yang telah dibangun pun bermacam macam, baik yang tertutup maupun yang berlubang. Salah satu struktur cangkang berlubang yang terkenal yaitu geodesic dome atau kubah geodesik.

Kubah geodesik pertama kali dibangun di jerman pada 1926 yang befungsi sebagai planetarium, yang dibangun oleh Walter Bauersfeld. Dia menyadari bahwa bangunan mampu untuk menahan badai dikarenakan gaya akan terdistribusi 
secara merata ke setiap batang dan mempunyai nilai estetika yang cukup bagus untuk dijadikan sebagai planetarium (Peng, 2016).

Analisis yang umum dilakukan adalah memodelkan struktur kubah geodesik sebagai rangka batang atau titik buhul nya sebagai sendi. Namun, untuk mengaplikasikan titik buhul sebagai sendi saat konstruksi tidaklah mudah. Selain itu, karenakan dimodelkan sebagai sendi maka gaya dalam yang timbul hanya gaya aksial. Namun, pada kenyataanya gaya dalam yang timbul ada gaya geser dan momen.

Penelitian ini menganalisis gaya-gaya dalam pada struktur kubah geodesik dengan memodelkan titik buhul sebagai sendi dan titik buhul sebagai rigid untuk mencari pemodelan mana yang lebih baik digunakan dalam menganalisis struktur kubah geodesik.

Berdasarkan latar belakang yang telah dijabarkan diatas, tujuan penelitian ini adalah mengetahui pemodelan mana yang lebih baik digunakan untuk menganalisis struktur kubah geodesik jika ditinjau dari nilai perpindahan. Tujuan lainnya adalah mengetahui pemodelan mana yang lebih baik digunakan jika ditinjau dari nilai - nilai gaya dalam yang timbul pada struktur.

\section{Subdivisi Geodesik}

Model Buckminster Fuller berdasarkan dari subdivisi dari bentuk dari bola yang dibagi membentuk icosahedron walaupun kubah geodesik sudah pernah di desain menggunakan octahedron dan dodechedron. Pada akhirnya bentuk octahedron yang digunakan untuk mendemonstrasikan konsep dari subdivisi, kelas, dan frekuensi.
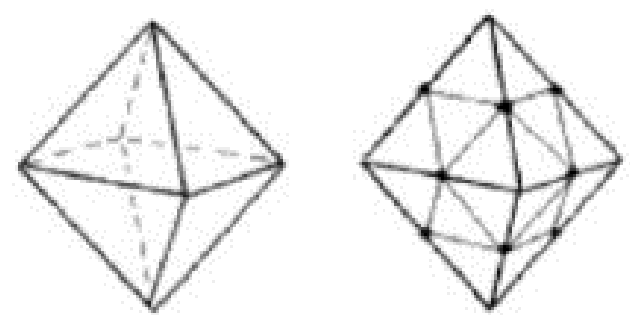

Gambar 1. Regular octahedron (Sumber: Kenner, 2003)

Gambar sebelah kiri pada gambar 1. menunjukkan bentuk regular octahedron, yang memiliki 8 bentuk segitiga. Untuk gambar sebelah kanan pada gambar 1 menunjukkan pembagian segitiga menjadi 4 bagian lebih kecil dengan menyambungkan titik tengah dari pinggir segitiga. 32 segitiga kecil pun memiliki sisi yang sama panjang, namun bentuk octahedron tidak sama dengan bentuk bola. Ini dikarenakan jarak dari titik pusat dari octahedron tidak memiliki jarak antara jarak ke titik tengah dan titik tegak lurusnya.
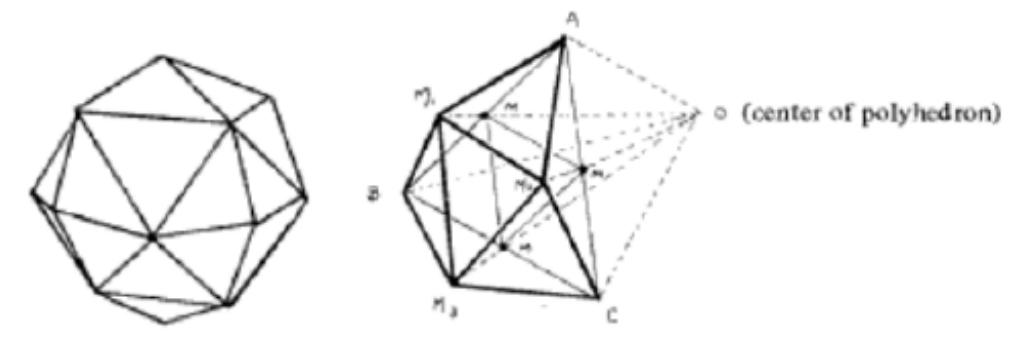

Gambar 2. Modified octahedron (Sumber: Kenner, 2003)

Konsep dari frekuensi ditentukan dengan jumlah dari segmen dimana prinsip dari subdivisi. 2V berarti segitiga yang dibagi menjadi 2 segmen sama besar, untuk 3V berarti membagi 3 segmen sama besar dan seterusnya. Ada 2 kelas dari subdivisi geodesik seperti yang ditampilakan pada gambar 2, untuk kelas I, segitiga dibagi secara parallel ke pinggir dari segitiga, dan kelas II, membagi garis dari tegak lurus dari pinggir segitiga. (Peng, 2016) 

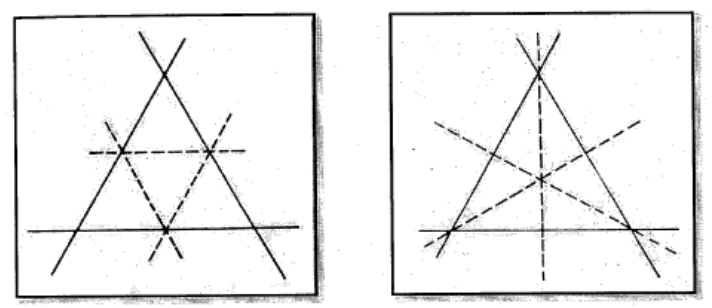

Gambar 3. Kelas 1 dan Kelas 2 pada kubah geodesik (Sumber: Kassim, 2015)

Ramaswamy (2002) menjelaskan untuk subdivisi kelas I memperbolehkan frekuensi ganjil dan genap, namun untuk subdivisi kelas II hanya diperbolehkan frekuensi genap. Untuk subdivisi kelas II memiliki panjang yang lebih pendek dan memiliki panjang yang bervariasi, namun distribusi tegangan tidak merata. Kubah yang memiliki frekuensi ganjil tidak dapat menghasilkan bentuk hemispherical dikarenakan hanya bisa dihasilkan oleh yang memiliki frekuensi genap.

Class I

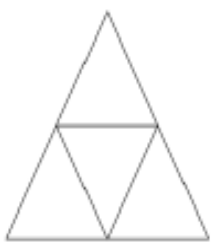

$2 v$

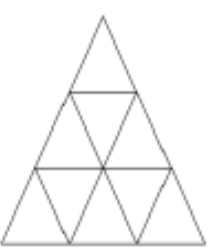

$3 v$

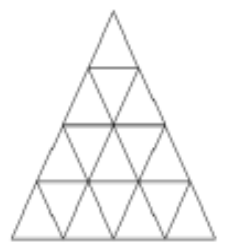

$4 \boldsymbol{V}$

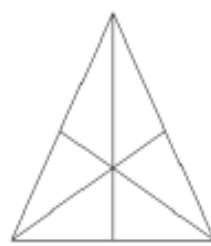

$2 V$

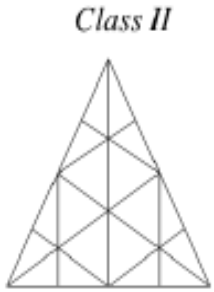

$4 V$

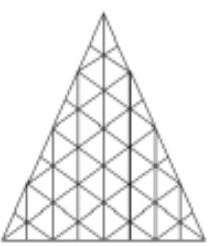

$8 \mathrm{~V}$

Gambar 4. Kelas dan frekuensi (Sumber: Salsburg dalam Peng, 2016)
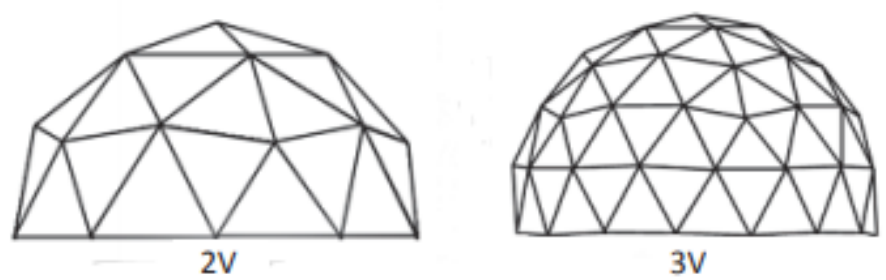

Gambar 5. Frekuensi pada kubah geodesik (Sumber: Kusuma, 2014)

\section{Baja cold-formed}

Baja cold-formed adalah baja dengan kualitas tinggi yang bersifat ringan dan tipis namun kekuatannya tidak kalah dengan baja konvensional. (Pangaribuan, 2014)

Menurut Yu dan LaBoube (2010) dalam bukunya menjelaskan, secara umum baja cold-formed memberikan beberapa keuntungan seperti:

1. Dibandingkan dengan bentuk baja hot-rolled, baja cold-formed dapat dimanufaktur dengan memiliki beban yang ringan dan/atau bentang yang pendek.

2. Konfigurasi penampang yang beragam dapat diproduksi secara ekonomis dengan cold-forming operation dan menyebabkan keseteraan antara kekuatan dengan berat dapat tercapai.

3. Penampang yang diproduksi dapat disatukan yang membuat pengemasan dan pengiriman lebih mudah.

4. Panel dan gelagak pemikul beban dapat memberikan penampang untuk lantai, atap, dan dinding, dan dalam kasus lain dapat digunakan sebagai penutup elektrik.

5. Panel dan gelagak pemikul beban tidak hanya dapat memikul beban normal, tetapi dapat menjadi penahan geser di bidangnya sendiri jika saling terhubung dan dapat mendukung antar member. 


\section{METODE PENELITIAN}

Metode elemen hingga adalah metode numerik yang digunakan untuk memenyelasaikan permasalahan mekanika kontinum dengan ketelitian yang cukup mudah dipahami. Hingga saat ini metode elemen hingga masih digunakan sebagai solusi menyelesaikan berbagai masalah. Metode elemen hingga dapat menganalisis elemen yang berbeda jenis dan bentuk yang sembarang. (Suryoatmono, 1990)
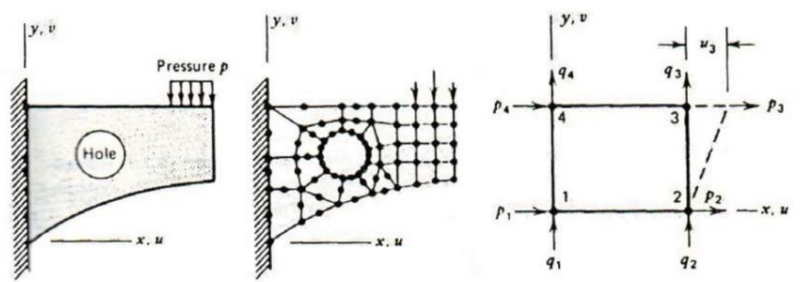

(a). Struktur aktual (b). Model elemen hingga. (c). Elemen segiempat bidang.

Gambar 6. Pemodelan elemen hingga (Sumber: Pranata, 2019)

\section{Langkah-langkah pemodelan struktur dengan program MIDAS GEN}

Berikut langkah-langkah pemodelan dan data pemodelan struktur pada program midas GEN.

1. Pemodelan

Kubah geodesik yang akan dimodelkan berdiameter $20000 \mathrm{~mm}$ dan tinggi $10000 \mathrm{mmm}$. Pemodelan dibuat dengan menggunakan arch. Pada menu structure $>$ Base Structure $>$ arch.
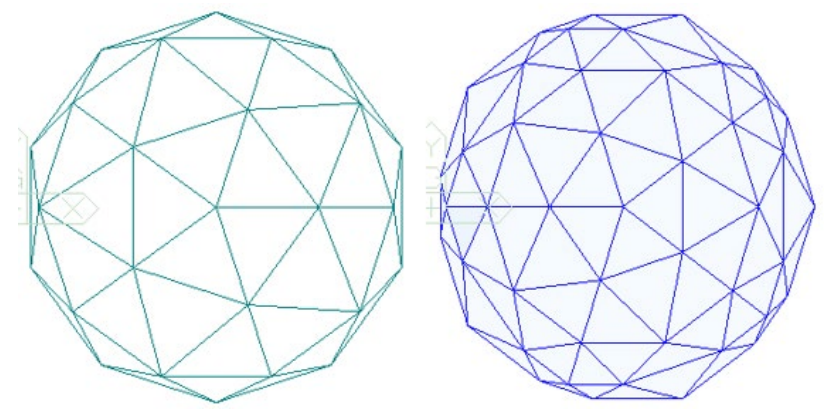

Gambar 7. Pemodelan struktur kubah geodesik tipe 2V dan 3V

\section{Data Material}

Data material pemodelan struktur kubah geodesik disajikan pada Tabel 1.

Tabel 1. Data material

\begin{tabular}{ccc}
\hline \multirow{2}{*}{ Data } & \multicolumn{3}{c}{ Nilai } \\
\cline { 2 - 3 } & $2 \mathrm{~V}$ & $3 \mathrm{~V}$ \\
\hline ID & 1 & 1 \\
Name & Steel & Steel \\
Standard & None & None \\
Type of Design & Steel & Steel \\
Type of Material & Isotropic & Isotropic \\
Modulus of Elasticity & $200000 \mathrm{~N} / \mathrm{mm}^{2}$ & $200000 \mathrm{~N} / \mathrm{mm}^{2}$ \\
Poisson's Ratio & 0.3 & 0.3 \\
Weight Density & $7.6982 \mathrm{e}-5 \mathrm{~N} / \mathrm{mm}^{3}$ & $7.6982 \mathrm{e}-5 \mathrm{~N} / \mathrm{mm}^{3}$ \\
\hline
\end{tabular}




\section{Properti}

Data properti pemodelan struktur kubah geodesik disajikan pada Tabel 2.

Tabel 2. Data properti

\begin{tabular}{ccc}
\hline \multirow{2}{*}{ Data } & \multicolumn{2}{c}{ Nilai } \\
\cline { 2 - 3 } & $2 \mathrm{~V}$ & $3 \mathrm{~V}$ \\
\hline Section ID & 1 & 1 \\
Name & Pipe & Pipe \\
Type of Material & Pipe & Pipe \\
User/DB & User & User \\
D & $114.3 \mathrm{~mm}$ & $89.1 \mathrm{~mm}$ \\
Tw & $3.6 \mathrm{~mm}$ & $2.8 \mathrm{~mm}$ \\
\hline
\end{tabular}

4. Beban dan Kombinasi Beban

Beban yang digunakan dalam penelitian ini berupa beban mati yaitu berat sendiri profil dan kaca dengan tebal 12 $\mathrm{mm}$, beban hidup sebesar $1.33 \mathrm{kN}$ pada nodal, dan beban angin dengan kecepatan angina dasar 85.67466 mile/hour. Untuk penelitian ini digunakan 6 kombinasi pembebanan seperti pada tabel dibawah.

Tabel 3. Kombinasi pembebanan yang dipakai

\begin{tabular}{cccc}
\hline \multirow{2}{*}{ Jenis Kombinasi } & \multicolumn{3}{c}{ Load Case \& Scale Factor } \\
\cline { 2 - 4 } & Beban Mati & Beban Hidup & Beban Angin \\
\hline Kombinasi 1 & 1.4 & - & - \\
Kombinasi 2 & 1.2 & 1.6 & 0.5 \\
Kombinasi 3 & 1.2 & - & - \\
Kombinasi 4 & 1.2 & 1 & 1 \\
Kombinasi 5 & 1.2 & 1 & 1 \\
Kombinasi 6 & 0.9 & - & \\
\hline
\end{tabular}

\section{Boundary Condition}

Pada penelitian ini akan digunakan perletakan sendi dimana gaya yang dapat ditahan adalah Dx, Dy, dan Dz.

\section{HASIL DAN PEMBAHASAN}

\section{Hasil nilai perpindahan berdasarkan program MIDAS GEN}

Nilai perpindahan yang dianalisis yaitu nilai perpindahan di puncak kubah dan perpindahan maksimum pada pemodelan sambungan titik buhul sebagai sendi dan sebagai rigid pada kubah geodesik tipe $2 \mathrm{~V}$ dan tipe $3 \mathrm{~V}$. hasil analisis nilai perpindahan yang diperoleh dari program MIDAS GEN untuk tipe 2V dengan titik buhul sebagai sendi dan rigid dapat dilihat pada tabel 2 dan tabel 3, sedangkan untuk tipe 3V dengan titik buhul sebagai sendi dan rigid dapat dilihat pada tabel 4 dan tabel 5.

Tabel 4. Nilai perpindahan dengan pemodelan sambungan titik buhul sebagai sendi pada kubah geodesik tipe $2 \mathrm{~V}$

\begin{tabular}{ccccc}
\hline \multirow{2}{*}{ No. } & \multirow{2}{*}{ Jenis Perpindahan } & \multicolumn{3}{c}{ Arah Perpindahan } \\
\cline { 3 - 5 } & & $\mathrm{X}$ & $\mathrm{Y}$ & $\mathrm{Z}$ \\
\hline 1 & Translasi di puncak $(\mathrm{mm})$ & 0.0601 & 0.0580 & -0.1044 \\
2 & Translasi maksimum $(\mathrm{mm})$ & 0.0936 & 0.0880 & -0.1115 \\
\hline
\end{tabular}


Tabel 5. Nilai perpindahan dengan pemodelan sambungan titik buhul sebagai rigid pada kubah geodesik tipe $2 \mathrm{~V}$

\begin{tabular}{ccccc}
\hline \multirow{2}{*}{ No. } & \multirow{2}{*}{ Jenis Perpindahan } & $\mathrm{X}$ & $\mathrm{Y}$ & $\mathrm{Z}$ \\
\cline { 3 - 5 } & & 0.0600 & 0.0579 & -0.1043 \\
\hline 1 & Translasi di puncak (mm) & 0.0003 & 0.0003 & 0.0000 \\
2 & Rotasi di puncak (rad) & 0.0934 & 0.0878 & -0.1114 \\
3 & Translasi maksimum (mm) & 0.0007 & 0.0007 & 0.0000 \\
4 & Rotasi maksimum (rad) & &
\end{tabular}

Tabel 6. Nilai perpindahan dengan pemodelan sambungan titik buhul sebagai sendi pada kubah geodesik tipe $3 \mathrm{~V}$

\begin{tabular}{ccccc}
\hline \multirow{2}{*}{ No. } & \multirow{2}{*}{ Jenis Perpindahan } & \multicolumn{3}{c}{ Arah Perpindahan } \\
\cline { 3 - 5 } & & $\mathrm{X}$ & $\mathrm{Y}$ & $\mathrm{Z}$ \\
\hline 1 & Translasi di puncak $(\mathrm{mm})$ & 0.0623 & 0.0624 & -0.1032 \\
2 & Translasi maksimum $(\mathrm{mm})$ & 0.1157 & 01125 & -0.1147 \\
\hline
\end{tabular}

Tabel 7. Nilai perpindahan dengan pemodelan sambungan titik buhul sebagai rigid pada kubah geodesik tipe $3 \mathrm{~V}$

\begin{tabular}{ccccc}
\hline \multirow{2}{*}{ No. } & \multirow{2}{*}{ Jenis Perpindahan } & \multicolumn{3}{c}{ Arah Perpindahan } \\
\cline { 3 - 5 } & & $\mathrm{X}$ & $\mathrm{Y}$ & $\mathrm{Z}$ \\
\hline 1 & Translasi di puncak $(\mathrm{mm})$ & 0.0619 & 0.0622 & -0.1032 \\
2 & Rotasi di puncak $(\mathrm{rad})$ & 0.0002 & 0.0002 & 0.0000 \\
3 & Translasi maksimum $(\mathrm{mm})$ & 0.1151 & 0.1120 & -0.1134 \\
4 & Rotasi maksimum $(\mathrm{rad})$ & 0.0008 & 0.0006 & 0.0000 \\
\hline
\end{tabular}

\section{Hasil gaya dalam berdasarkan program MIDAS GEN}

Nilai gaya dalam yang dianalisis yaitu nilai gaya dalam pada pemodelan sambungan titik buhul sebagai sendi dan sebagai rigid pada kubah geodesik tipe $2 \mathrm{~V}$ dan tipe $3 \mathrm{~V}$, berikut hasil analisis nilai perpindahan yang diperoleh dari program MIDAS GEN untuk tipe 2V dapat dilihat pada tabel 6, sedangkan untuk tipe $3 \mathrm{~V}$ dapat dilihat pada tabel 7. Hasil akan di cek menggunakan design code AISC(15th) - LFRD 16.

Tabel 8. Nilai gaya dalam pada elemen batang kubah geodesik tipe $2 \mathrm{~V}$

\begin{tabular}{|c|c|c|c|c|c|c|}
\hline \multirow[b]{2}{*}{ No. } & \multirow{2}{*}{$\begin{array}{l}\text { Jenis } \\
\text { Sambungan } \\
\text { Titik Buhul }\end{array}$} & \multicolumn{5}{|c|}{ Besar Nilai } \\
\hline & & Gaya Aksial (kN) & $\begin{array}{c}\text { Gaya Geser } \\
\text { y }(\mathrm{kN})\end{array}$ & $\begin{array}{c}\text { Gaya Geser } \\
\text { z }(\mathrm{kN})\end{array}$ & $\begin{array}{l}\text { Momen - My } \\
(\mathrm{kNm})\end{array}$ & $\begin{array}{c}\text { Momen }-\mathrm{Mz} \\
(\mathrm{kNm})\end{array}$ \\
\hline 1. & Sendi & -2.0564 & - & - & - & - \\
\hline 2. & $\begin{array}{l}\text { Rigid (momen } \\
\text { maksimum) }\end{array}$ & -0.2701 & 0.0134 & -0.3604 & -0.4350 & 0.0361 \\
\hline 3. & $\begin{array}{c}\text { Rigid (aksial } \\
\text { maksimum) }\end{array}$ & -2.0600 & 0.0600 & 0.1300 & -0.0800 & -0.1500 \\
\hline
\end{tabular}

Tabel 9. Nilai gaya dalam pada elemen batang kubah geodesik tipe $3 \mathrm{~V}$

\begin{tabular}{ccccccc}
\hline & Jenis & \multicolumn{5}{c}{ Besar Nilai } \\
\cline { 3 - 6 } No. & $\begin{array}{c}\text { Sambungan } \\
\text { Titik Buhul }\end{array}$ & Gaya Aksial $(\mathrm{kN})$ & $\begin{array}{c}\text { Gaya Geser } \\
\mathrm{y}(\mathrm{kN})\end{array}$ & $\begin{array}{c}\text { Gaya Geser } \\
\mathrm{z}(\mathrm{kN})\end{array}$ & $\begin{array}{c}\text { Momen }- \text { My } \\
(\mathrm{kNm})\end{array}$ & $\begin{array}{c}\text { Momen }-\mathrm{Mz} \\
(\mathrm{kNm})\end{array}$ \\
\hline 1. & $\begin{array}{c}\text { Sendi } \\
\text { Rigid (momen } \\
\text { maksimum) }\end{array}$ & -1.6154 & - & - & - & - \\
2. & 0.3074 & 0.0010 & -0.2221 & -0.1846 & -0.0029 \\
3. & $\begin{array}{c}\text { Rigid }(\text { aksial } \\
\text { maksimum) }\end{array}$ & -1.6200 & 0.0100 & -0.0300 & 0.0100 & 0.0100 \\
\hline
\end{tabular}




\section{Pembahasan}

Dari nilai perpindahan pada tabel 4 dan tabel 5 kubah geodesik tipe $2 \mathrm{~V}$, terlihat bahwa nilai perpindahan translasi untuk arah $\mathrm{X}$, arah $\mathrm{Y}$, dan arah Z pada pemodelan sambungan titik buhul sebagai Sendi lebih besar dibandingkan dengan pemodelan sambungan titik buhul sebagai rigid dengan nilai tranlasi pemodelan titik buhul sebagai Sendi lebih tinggi $0.21 \%$ untuk arah X lalu $0.21 \%$ untuk arah Y, dan $0.05 \%$ untuk arah Z. Hal ini dikarenakan beban yang diterima oleh pemodelan titik buhul sebagai Sendi akan diubah menjadi beban aksial. Sedangkan untuk nilai rotasi, pemodelan titik buhul sebagai rigid lebih besar dibandingkan dengan pemodelan sambungan titik buhul pada sendi.

Untuk nilai perpindahan pada tabel 6 dan tabel 7 kubah geodesik tipe $3 \mathrm{~V}$, nilai translasi untuk arah X, arah Y, dan arah $\mathrm{Z}$ pada pada pemodelan sambungan titik buhul sebagai Sendi lebih besar dibandingkan dengan pemodelan sambungan titik buhul sebagai rigid dengan nilai tranlasi pemodelan titik buhul sebagai sendi lebih tinggi $0.51 \%$ untuk arah X lalu $0.46 \%$ untuk arah Y, dan $1.07 \%$ untuk arah Z. Sedangkan untuk nilai rotasi, pemodelan titik buhul sebagai rigid lebih besar dibandingkan dengan pemodelan sambungan titik buhul pada Sendi.

Nilai perpindahan yang diambil di puncak kubah geodesik pada tabel 4 dan tabel 6 , dapat dilihat bahwa perbedaan perpindahan antara kedua tipe kubah geodesik relatif kecil. Untuk pemodelan sambungan titik buhul sebagai sendi pada kubah geodesik tipe 3V lebih tinggi $3.53 \%$ untuk perpindahan translasi arah X dan $7.05 \%$ untuk arah Y. Untuk perpindahan translasi arah Z, pemodelan sambungan titik buhul sebagai sendi pada kubah geodesik tipe $2 \mathrm{~V}$ memiliki nilai lebih tinggi $1.15 \%$ dibanding tipe kubah geodesik $3 \mathrm{~V}$.

Nilai perpindahan pada pemodelan sambungan titik buhul sebagai rigid di puncak kubah pada tabel 5 dan tabel 7 , didapat nilai perpindahan pada kubah geodesik 3V memiliki nilai yang lebih tinggi sebesar 3.07\% untuk arah X dan $6.91 \%$ untuk arah Y. Untuk perpindahan translasi arah Z, pemodelan sambungan titik buhul sebagai sendi pada kubah geodesik tipe $2 \mathrm{~V}$ memiliki nilai lebih tinggi $1.05 \%$ dibanding tipe kubah geodesik $3 \mathrm{~V}$.

Dari hasil analisis gaya aksial pada tabel 8 dan tabel 9 dalam pada pemodelan sambungan titik buhul sebagai sendi baik pada tipe kubah $2 \mathrm{~V}$ dan $3 \mathrm{~V}$, keduanya memenuhi syarat yaitu rasio antara gaya aksial dengan kapasitas gaya aksial harus kurang dari satu. Cek syarat tersebut di dapat dengan bantuan program MIDAS GEN. Berikut merupakan hasil dari pengecekan gaya aksial maksimum terhadap kapasitas aksial elemen pada kubah geodesik tipe $2 \mathrm{~V}$ dan $3 \mathrm{~V}$

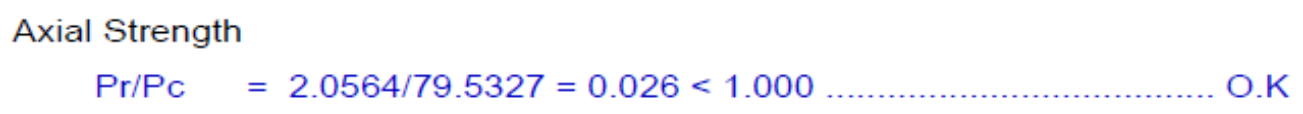

Gambar 8. Cek Syarat Rasio Gaya Aksial Maksimum dengan Kapasitas Aksial pada Kubah Geodesik Tipe 2V

Axial Strength

$\mathrm{Pr} / \mathrm{Pc} \quad=1.6154 / 62.7976=0.026<1.000$ O.K

Gambar 9. Cek Syarat Rasio Gaya Aksial Maksimum dengan Kapasitas Aksial pada Kubah Geodesik Tipe 3V Pada gambar 10 dan gambar 11 dilakukan pengecekan gaya aksial maksimum dengan tetap memperhatikan nilai gaya dalam pada kubah geodesik tipe $2 \mathrm{~V}$ dan $3 \mathrm{~V}$.

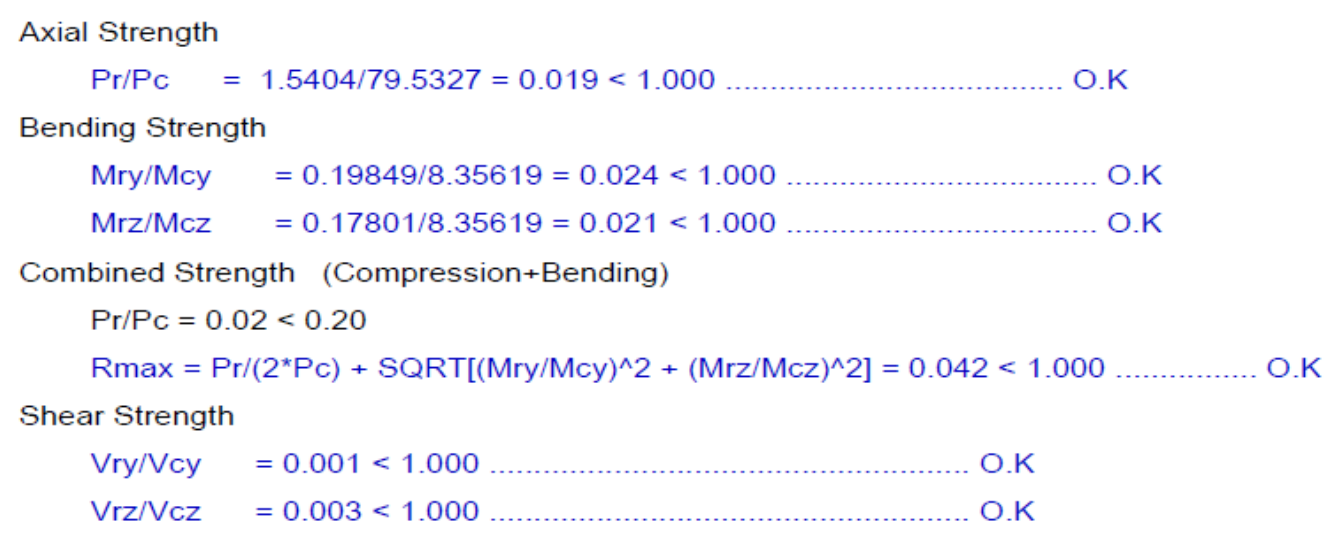

Gambar 10. Cek Syarat Gaya Aksial Maksimum dan Gaya Dalam Lainnya pada Kubah Geodesik Tipe 2V 


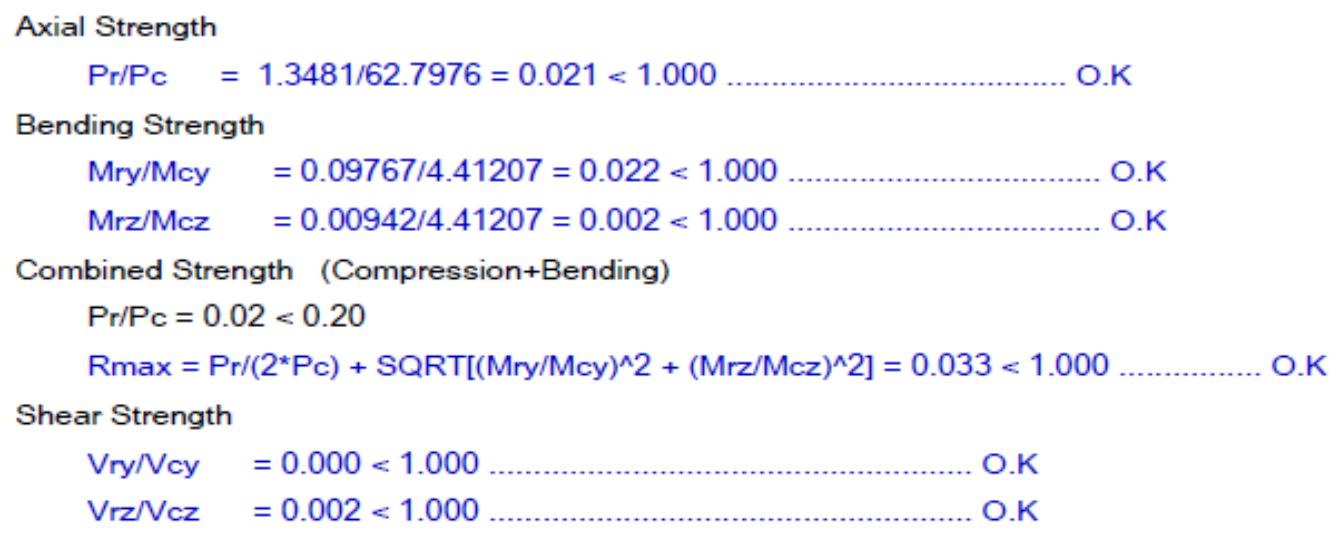

Gambar 11. Cek Syarat Gaya Aksial Maksimum dan Gaya Dalam Lainnya pada Kubah Geodesik Tipe 3V Kemudian dilakukan pengecekan momen maksimum beserta gaya dalam lainnya pada kubah geodsik tipe $2 \mathrm{~V}$ yang ditunjukkan pada gambar 12 dan tipe $3 \mathrm{~V}$ pada gambar 13.

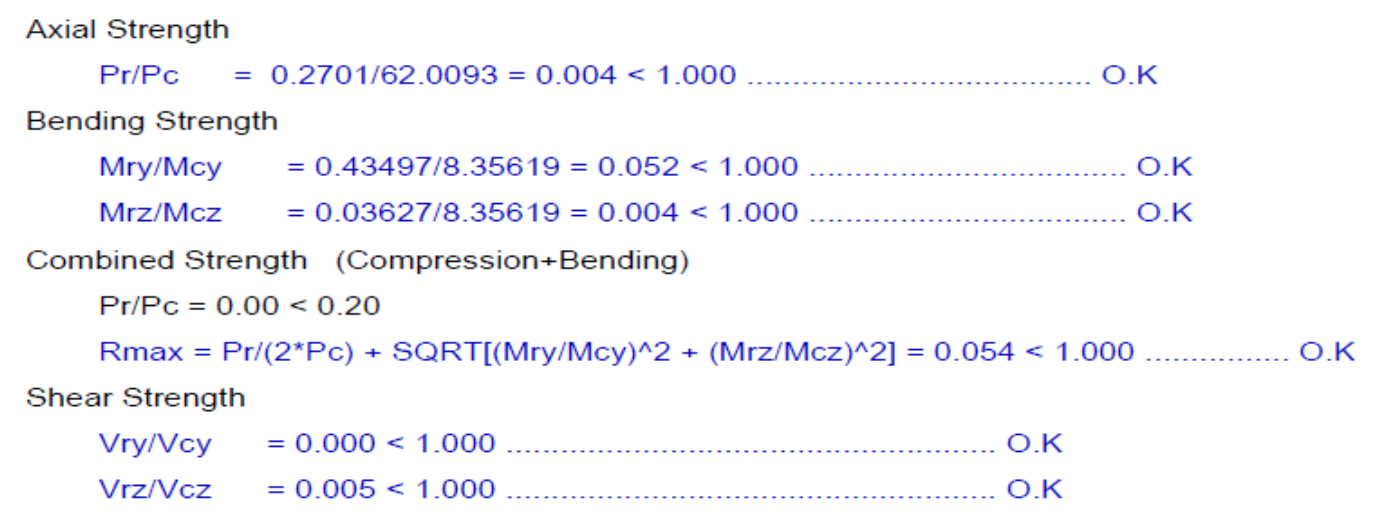

Gambar 12. Cek Syarat Momen Maksimum dan Gaya Dalam Lainnya pada Kubah Geodesik Tipe 2V

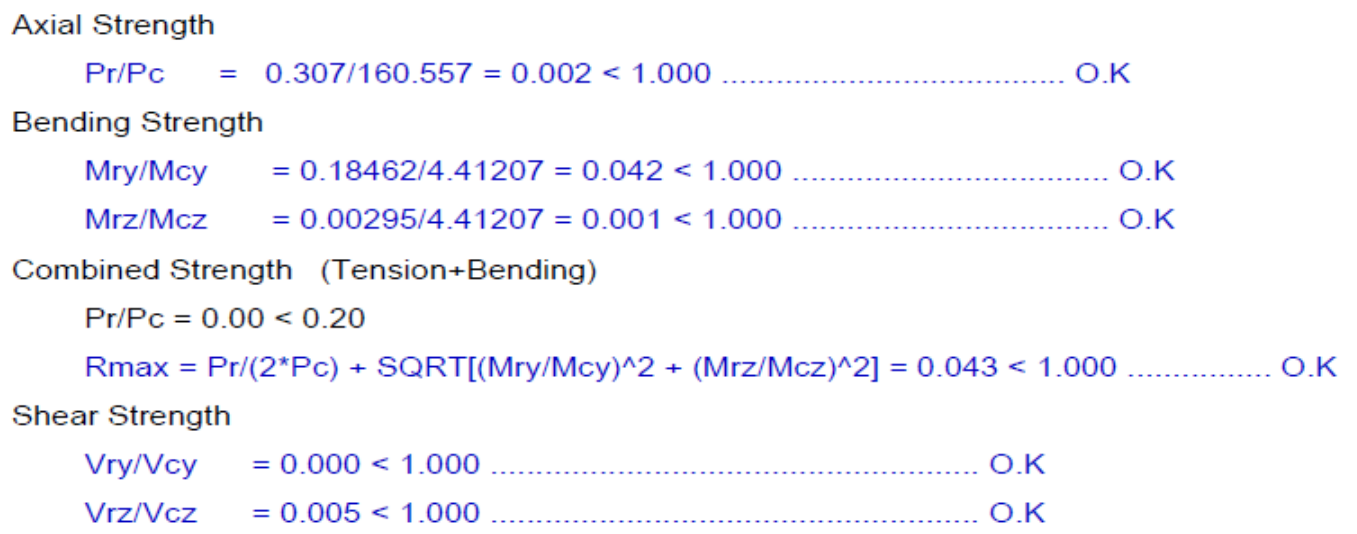

Gambar 13. Cek Syarat Momen Maksimum dan Gaya Dalam Lainnya pada Kubah Geodesik Tipe 3V

Pengecekan yang dilakukan pada gambar 8 sampai gambar 13 menunjukkan bahwa kubah geodesik yang digunakan dalam penelitian kuat terhadap gaya dalam yang diberikan baik kubah geodesik tipe $2 \mathrm{~V}$ maupun tipe $3 \mathrm{~V}$. 


\section{KESIMPULAN}

\section{Kesimpulan}

Berdasarkan analisis dan pembahasan yang telah dilakukan, kesimpulan yang dapat diambil dari penelitian ini adalah sebagai berikut.

1. Dari nilai perpindahan, dapat disimpulkan bahwa untuk kubah geodesik tipe $2 \mathrm{~V}$ dan tipe $3 \mathrm{~V}$ dapat dimodelkan baik dengan pemodelan sambungan titik buhul sebagai sendi maupun sebagai rigid. Hal ini dikarenakan perpindahan translasi yang timbul pada kedua pemodelan sambungan titik buhul relatif kecil perbedaannya.

2. Sebaiknya analisis dilakukan dengan pemodelan sambungan titik buhul sebagai rigid. Karena dari hasil analisis gaya dalam yang timbul akibat beban yang bekerja pada kedua pemodelan, gaya aksialnya relatif sama. Namun, pada pemodelan sambungan titik buhul sebagai rigid ada timbul momen.

\section{Saran}

Berdasarkan proses pengerjaan dan studi kasus ini, ada beberapa hal yang dapat diperbaiki agar dapat memberikan manfaat yang lebih. Oleh karena itu, pengembangan yang dapat dilakukan untuk studi selanjutnya diantara lain:

1. Dapat dicoba menambahkan beban akibat gempa pada struktur ini.

2. Dapat dilakukan analisis dengan ukuran penampang yang bervariasi.

3. Untuk analisis yang lebih akurat, dapat dilakukan pemodelan pada tipe kubah geodesik lainnya.

4. Dapat dilakukan analisis menggunakan perletakan sebagai pegas.

\section{DAFTAR PUSTAKA}

Kassim, Mabin ABD. Finite Element AnalysisOf A Geodesic Dome Structure By Using Staadpro Software. Tesis, Universiti Malaysia Pahang, 2015.

Kenner, Hugh. Geodesic Math and How to Use It, 2nd edn, University of California Press Berkeley, Los Angeles, London, 2003.

Kusuma, Christianto C. Perancangan Struktur Kubah Geodesik Baja Sebagai Hunian Semi Permanen Korban Bencana Alam. S1 thesis, UAJY, 2014.

Pangaribuan, Mekar R. "Baja Ringan Sebagai Pengganti Kayu Dalam Pembuatan Rangka Atap Bangunan Rumah Masyarakat". Jurnal Teknik Sipil dan Lingkungan, vol. 2, no. 2, 2014, pp. 648-655.

Peng, Zhuohao. Geodesic Dome Structural Analysis and Design. dissertation, University of Southern Queensland, 2016.

Pranata, Yosafat A. Diktat Kuliah Metode Elemen Hingga. Bandung : Universitas Kristen Maranatha, 2019.

Ramaswamy, SG, et al. Analysis, design and construction of steel space frames, Thomas Telford Ltd, London, 2002.

Yu, Wei-Wen, et al. Cold-formed steel design. Vol. 4. Hoboken, NJ: Wiley, 2010. 
